Yu.V. Batygin, S.O. Shinderuk, E.O. Chaplygin

\title{
Mutual influence of currents in a flat inductor system with solenoid between two massive conductors
}

Introduction. Inductor systems, as tools for metal processing, are widely used in industrial technologies using the energy of powerful pulsed electromagnetic fields. Problem. A common disadvantage of the known works on the creation of tools for magnetic-pulse impact on conductive objects is the use physical and mathematical models, in which the exciting currents do not depend on the ongoing electromagnetic processes. Such the assumption distorts the picture of the real energy in the working area of the inductor system. Goal. To obtain design relationships and numerical estimations of the mutual influence of exciting and induced currents of a flat inductor system with a circular solenoid located between massive well-conducting objects, moreover to carry out a theoretical analysis of electromagnetic processes in this system. Methodology. Applied integrating Maxwell equations using the Laplace and Fourier-Bessel integral transforms in the approximation of the ideal conductivity of the metal objects to be processed. Results. The calculated relationships for the theoretical analysis of electromagnetic processes are obtained in the high-frequency approximation. It is shown that the inductance of the studied system decreases as the objects being processed approach the solenoid and increases as they move away from it. It is found that for the invariability of the power indicators, of the proposed tool, a corresponding correction of the amplitude (on average up to 20 times) of the exciting current is necessary in the solenoid winding. Originality. For the first time, the tool design with a circular solenoid located between the massive metal objects is proposed for flat magnetic-pulse stamping. As a result of the theoretical analysis, the influence of electromagnetic processes on the currents flowing in the system is confirmed. Practical significance. The use of the results obtained will allow to increase the efficiency of the tool of magnetic-pulse technologies, and to reduce the energy costs for performing the specified production operations. References 19, figures 2.

Key words: magnetic-pulse stamping, sheet metals, electromagnetic fields, inductor systems, circular solenoid, massive conductor.

В роботі розглянута плоска індукторна система з круговим соленоїдом, розташованим між масивними добре провідними об'єктами. Така конструкиія спрямована не тільки на підвищення ефективності інструменту магнітно-імпульсних технологій, та на зниження енергетичних витрат на виконання заданої виробничої операції. Інтегруванням рівнянь Максвелла з використанням інтегральних перетворень Лапласа $і$ Фур'є-Бесселя в наближенні ідеальної провідності металевих об'єктів, щзо підлягають обробиі, аналітично отримано математичну модель системи. В рамках поставленої мети отримано розрахункові співвідношення $і$ проведено теоретичний аналіз електромагнітних прочесів в плоскій індукторній системі з круговим соленоїдом, що розміщений між масивними добре провідними об'єктами, а також проведено чисельні оцінки взаємного впливу збуджуючих і індукованих струмів. Результати аналізу електромагнітних прочесів показали, що для незмінності силових показників запропонованого інструменту магнітно-імпульсного штампування необхідна відповідна корекиія амплітуди збуджуючого струму в обмотиі соленоїда - джерела діючих електромагнітних полів. Бібл. 19, рис. 2.

Ключові слова: магнітно-імпульсне штампування, листові метали, електромагнітні поля, індукторні системи, круговий соленоїд, масивний провідник.

В работе рассмотрена плоская индукторная система с круговым соленоидом, расположенным между массивными хорошо проводящиим объектами. Такая конструкияя направлена не только на повышение эффективности инструмента магнитно-импульсных технологий, но и снижение энергетических затрат на выполнение заданной производственной операчии. Интегрированием уравнений Максвелла с использованием интегральных преобразований Лапласа и ФурьеБесселя в приближении идеальной проводимости подлежсащих обработке металлических объектов аналитически получено математическую модель системы. В рамках поставленной иели получены расчётные соотношения и проведен теоретический анализа электромагнитных процессов в плоской индукторной системе с круговым соленоидом, размещённым между массивными хорошо проводящими объектами, а также проведены численные оценки взаимного влияния возбуждающих и индуцированных токов. Результаты анализа электромагнитных процессов показали, что для неизменности силовых показателей предложенного инструмента магнитно-импульсной штамповки необходима соответствующая коррекиия амплитуды возбуждающего тока в обмотке соленоида - источника действующих электромагнитных полей. Библ. 19, рис. 2.

Ключевые слова: магнитно-импульсная штамповка, листовые металлы, электромагнитные поля, индукторные системы, круговой соленоид, массивный проводник.

Introduction. Problem definition in general. Inductor systems, as tools for metal processing, are widely used in industrial technologies using the energy of powerful pulsed electromagnetic fields. The design of induction systems is determined by the type of given production operation (for example, «distribution», «crimping», «flat stamping», etc.). Note that their successful practical implementation, as described in the modern special literature, is carried out in the framework of the so-called «traditional» magnetic pulse treatment of metals (MPTM) or in Western terminology Electromagnetic Metals Forming (EMF). As practice has shown, the effectiveness of this technology is possible

(C) Yu.V. Batygin, S.O. Shinderuk, E.O. Chaplygin 
only in the range of sufficiently high operating frequencies of acting fields and high values of electrical conductivity of the processed objects. From a physical point of view, the natural Lorentz repulsion of the conductor from the instrument with the method, called «magnetic pressure» [1-4], is used here.

The development of electromagnetic technologies and increasing requirements for their efficiency has led to the creation of new types of induction systems. A number of production operations initiated a new direction of magnetic pulse processing of metals, based on the transformation of natural Lorentz repulsion in the attraction of the processed object [5-9]. As part of the «traditional» magnetic pulse treatment of metals, it seems a priori, increase in the productivity of flat stamping operations of sheet metal products is possible with the help of so-called «two-sided induction systems», where the solenoid is placed between objects of force action. The development of new tools requires the study of the processes of electromagnetic effects of exciting and induced currents. The relevance of such works is beyond doubt. The obtained results will allow to take a new approach to the problems of productivity, to increase the efficiency of inductor systems and expand the range of processed objects.

Literature review. Analysis of basic research and publications and problem definition. The twosided arrangement of sheet metals relative to the source of the magnetic field (solenoid) takes place in induction systems, where the natural Lorentz repulsion is transformed into the attraction of a specified area of the processed object. Structurally, such tools consist of flat layered: the auxiliary screen, which conducts electric current, the circular solenoid and, naturally, the sheet metal to be deformed. The currents induced in the screen and the metal being processed are unidirectional. According to Ampere law, a certain area of sheet metal will be attracted to the plane of the rigidly fixed screen [10]. This principle of operation is also used in systems of automated supply of aluminum sheets to the working area of the stamping equipment of US car plants [11]. Practical aspects of MPTM development in the direction of attracting specified areas of sheet metals and creating appropriate tools for removing dents are described in [2, 3, 12]. Note that, mainly, magnetic-pulse attraction has found application in advanced technologies for the restoration of damaged coatings of car bodies [9, 10, 12, 13].

Object of study. Consider the induction effects in tools for flat magnetic-pulse stamping of solid sheet metal products with high electrical conductivity, where the solenoid is placed between two objects of force action. The physical idea of such a design of the inductor system involves the concentration of energy of the excitation field in the space between two conductors. Unlike the known tools for «traditional» flat magnetic pulse stamping, where the solenoid is placed over a single object of force action, this proposal reduces the scattering of energy generated in the surrounding space.
A common disadvantage of the known works on the creation of instruments of force magnetic-pulse influence on conductive objects (both attraction and repulsion) is the use of physical and mathematical models in which the excitation currents are accepted given and independent on electromagnetic processes. Thus, in [9] in inductor systems, mechanical forces in the form of attractive forces and their distribution in the system were considered, but the mutual influence of currents in the inductor system remained unexplored. We should also mention classical analytical $[14,15]$ and modern numerical models, for example, in $[16,17]$.

From a phenomenological point of view, it is obvious that such an assumption in the definition of the electrodynamic problems to be solved distorts the picture of real energy in the working zone of the inductor system.

The goal of the paper is to obtain calculation relationships and to carry out theoretical analysis of electromagnetic processes in a flat inductor system with a circular solenoid placed between massive well-conducting objects, as well as to obtain numerical estimations of the mutual influence of excitation and induced currents. We emphasize the relevance of this goal, which is aimed not only at improving the efficiency of the tool of magnetic pulse technology, but also to reduce energy costs to perform a specified production operation.

Presentation of the main material. Analytical dependencies, numerical estimations. Concerning problems in MPTM inductor systems, we begin consideration with definition of problems which is identical for all researches of the proceeding electrodynamic processes [2, 8-12].

Assumptions for solving the formulated problem:

- a physical and mathematical model of the inductor system is symmetrical about the plane of the exciting solenoid (Fig. 1);

- a cylindrical coordinate system is adopted;

- a inductor system is assumed to be axially symmetric, i.e. $\frac{\partial}{\partial \varphi}=0$, where $\varphi$ is the azimuthal angle;

- a solenoid is assumed to be so thin that its metal does not affect the electromagnetic processes occurring in the system $(\Delta \rightarrow 0)$;

- an azimuthal harmonic current $J(t)=J_{\mathrm{m}} \cdot \sin (\omega \cdot t)$ flows in the solenoid winding, where $J_{\mathrm{m}}$ is the amplitude; $\omega$ is the cyclic frequency; $t$ is the time;

- sheet metals (plates that conduct electricity) are quite massive and have a high specific conductivity;

- in the system the azimuthal component of the electric field strength $E_{\varphi}(t, r, z) \neq 0$ is excited, as well as the radial $r$ and normal $z$ components of the magnetic field strength vector $H_{\mathrm{r}}(t, r, z) \neq 0$ and $H_{\mathrm{z}}(t, r, z) \neq 0$ accordingly;

- electromagnetic processes are assumed to be quasistationary, so $(\omega \cdot l / c)<<1$, where $c$ is the speed of light in vacuum; $l$ is the largest characteristic size of the system. 
The evaluation of the characteristics of the mutual influence of induced and excitation currents can be carried out based on the equality of the average values of the normal components of the magnetic flux density in the inner window of the solenoid at different distances between it and the plates.

In addition to the accepted assumptions, it should be noted that in practice the massiveness and high electrical conductivity of sheet metals means the operation of the inductor system in high-frequency temporal mode, when there is no penetration of fields through the processed objects. Within these studies, they can be considered as ideal conductors for which $\omega \cdot \tau \gg>1$, where $\omega \cdot \tau$ is the «electrodynamic» thickness (the introduction of the term is justified in $[9,10]) ; \tau=\mu_{0} \cdot \gamma \cdot d^{2}$ is the characteristic time of penetration of the field into the non-magnetic conducting layer; $\mu_{0}$ is the magnetic permeability of the vacuum; $\gamma$ is the specific electrical conductivity, and $d$ is the geometric thickness.

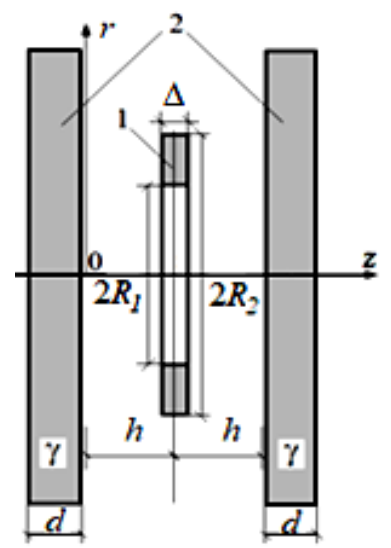

Fig. 1. Calculation model of flat inductor system: 1 - circular solenoid ( $\Delta$ - thickness, $R_{1,2}-$ inner and outer radii); 2 - sheet metals ( $d$ - thickness, $\gamma$ - specific electrical conductivity)

It is a priori obvious that the influence of induced currents on electromagnetic processes should decrease with the removal of sheet metals and increase with their approach to the exciting solenoid. In this regard, to describe the studied effect, we can identify and propose two main characteristics of the electromagnetic processes that take place. The first one is the ratio of the inductance of the system at different distances between the solenoid and the sheet metals to the inductance at infinite distance of the latter. The second one is the corresponding ratio of the resulting current in the solenoid winding to the excitation current in the absence of sheet metals. Note that the latter characteristic can be taken as a quantitative indicator of the effect of induced currents on the current in the solenoid winding.

Based on the accepted assumption of equality of average values of normal components of magnetic flux density in the inner window of the solenoid at different distances of sheet metals, we can obtain the following dependencies to assess the mutual influence of excitation and induced currents [14]:

$$
\left\{\begin{array}{l}
\bar{B}_{\mathrm{h}}=\bar{B}_{\infty} ; \\
\frac{J_{\mathrm{h}}}{J_{\infty}}=\frac{L_{\infty}}{L_{\mathrm{h}}} ;
\end{array}\right.
$$

where $\bar{B}_{\mathrm{h}}, J_{\mathrm{h}}, L_{\mathrm{h}}$ are the average value of the normal component of the magnetic flux density, the current in the solenoid winding and the inductance of the system at the final distance $h$ between the solenoid and the sheet metals, respectively; $\bar{B}_{\infty}, J_{\propto}, L_{\propto}$ are the average value of the normal component of the flux density, the current in the solenoid winding and the inductance of the system in the absence of sheet metals (at $h \rightarrow \infty$ ), respectively.

It should be noted that effectively relations (1) are consistent with the known dependencies [14]. Indeed, the amplitudes of the currents in the windings are inversely proportional to their inductance.

In accordance with the formulated goal, we turn to the calculation model in Fig. 1, for which we write a system of Maxwell equations in the space of $L$-images according to Laplace $[9,10,18,19]$

$$
\left\{\begin{array}{l}
\frac{\partial E_{\varphi}(p, r, z)}{\partial z}=\mu_{0} p H_{\mathrm{r}}(p, r, z) \\
\frac{1}{r} \cdot \frac{\partial}{\partial r} \cdot\left(r \cdot E_{\varphi}(p, r, z)\right)=-\mu_{0} p H_{\mathrm{z}}(p, r, z) \\
\frac{\partial H_{\mathrm{r}}(p, r, z)}{\partial z}-\frac{\partial H_{\mathrm{z}}(p, r, z)}{\partial r}=j_{\varphi 0}(p, r, z)
\end{array}\right.
$$

where

$E_{\varphi}(p, r, z)=\mathrm{L}\left\{E_{\varphi}(t, r, z)\right\}, H_{\mathrm{r}, \mathrm{z}}(p, r, z)=\mathrm{L}\left\{H_{\mathrm{r}, \mathrm{z}}(t, r, z)\right\}$, $j_{\varphi 0}(p, r, z)=\left\{j_{\varphi 0}(t, r, z)\right\}, \quad j_{\varphi 0}(t, r, z)$ is the current density in the solenoid, $j_{\varphi 0}(p, r, z)=j_{\mathrm{m}} \cdot g(t) \cdot f(r) \cdot \delta(z-h), g(t)$ is the temporal dependence; $f(r)$ is the radial dependence; $\delta(z-h)$ is the Dirac function [18].

We integrate the system of equations (1) in the same way as it was done earlier in $[2,9,10]$.

The geometry of the inductor system and the accepted assumptions allow us to apply the FourierBessel integral transform $[18,19]$.

For $L$-images of the excited electric field strength $E_{\varphi}(p, r, z)$ we write that

$$
\left\{\begin{array}{l}
E_{\varphi}(p, r, z)=\int_{0}^{\infty} E_{\varphi}(p, \lambda, z) \cdot \lambda \cdot J_{1}(\lambda r) d \lambda, \\
E_{\varphi}(p, \lambda, z)=\int_{0}^{\infty} E_{\varphi}(p, r, z) \cdot r \cdot J_{1}(\lambda r) d r,
\end{array}\right.
$$

where $E_{\varphi}(p, \lambda, z)$ is the image of electric field strength in Fourier-Bessel space; $\lambda$ is the integral transform parameter; $J_{1}(\lambda r)$ is the Bessel function of the first order.

Omitting intermediate mathematical transformations, from the system (1) using the integral image (2) we write the differential equation for the azimuthal component of the excited electric field strength in the inner cavity of the considered inductor system [18]. 


$$
\frac{\partial^{2} E_{\varphi}(p, \lambda, z)}{\partial z^{2}}-\lambda^{2} \cdot E_{\varphi}(p, \lambda, z)=K(p, \lambda) \cdot \delta(z-h),
$$

where $K(p, \lambda)=\mu_{0} p \cdot j_{\mathrm{m}} \cdot g(p) \cdot f(\lambda) ; \quad j_{\mathrm{m}}=\frac{J_{\mathrm{m}}}{\left(R_{2}-R_{1}\right)}$ is the excited current density;

$$
g(p)=\mathrm{L}\{g(t)\} ; f(\lambda)=\int_{R_{1}}^{R_{2}} f(r) \cdot r \cdot J_{1}(\lambda r) d r .
$$

The general integral of the ordinary differential equation (4) has the form [18]:

$$
\begin{aligned}
& E_{\varphi}(p, \lambda, z)=\mathrm{C}_{1} \cdot e^{\lambda z}+C_{2} \cdot e^{-\lambda z}+ \\
& +\frac{K(p, \lambda)}{\lambda} \cdot \eta(z-h) \cdot \operatorname{sh}(\lambda \cdot(z-h)),
\end{aligned}
$$

where $C_{1,2}$ are the arbitrary integration constants; $\eta(z-h)$ is the Heaviside step function.

The accepted assumption of the absence of field penetration through sheet metals, as already mentioned, is described by the inequality $\omega \cdot \tau \gg 1[2,6]$, which corresponds to their «ideal» conductivity. Satisfying the boundary conditions of the continuity of the tangential components of the electromagnetic field strength vector on the surfaces of ideal conductors at $z=0$ $\left(E_{\varphi}(p, \lambda, z=0)=0\right)$ and $z=2 h \quad\left(E_{\varphi}(p, \lambda, z=2 h)=0\right)$ [14], we find a partial solution of equation (3). Substituting the coordinate $z=h$ into the obtained expression, we obtain the image of the excited highfrequency electric field in the inner window of a flat circular solenoid of the considered inductor system.

$$
E_{\varphi}(p, \lambda, z=h)=-\frac{K(p, \lambda)}{2 \lambda} \cdot \operatorname{th}(\lambda h) .
$$

The integral image (2) taking into account (5) takes the form:

$$
E_{\varphi}(p, r, z)=-\int_{0}^{\infty} \frac{K(p, \lambda)}{2} \cdot \operatorname{th}(\lambda h) \cdot J_{1}(\lambda r) d \lambda .
$$

The connection of the $L$-image of the normal component of the excited magnetic field strength with the $\varphi$-component of the electric field strength in the inner window of the solenoid is found by the second equation from the system (1) by substitution $z=h$

$$
H_{z}(p, r, z=h)=-\frac{1}{\mu_{0} p} \cdot \frac{1}{r} \cdot \frac{\partial}{\partial r} \cdot\left(r \cdot E_{\varphi}(p, r, z=h)\right) .
$$

By integrating expression (8) along the plane of the inner window of the solenoid, we determine the relationship of the magnetic flux with $E_{\varphi}(p, r, z=h)$

$$
\begin{aligned}
& \Phi_{\mathrm{h}}(p)=2 \pi \mu_{0} \cdot \int_{0}^{R_{1}} H_{\mathrm{z}}(p, r, z=h) r d r= \\
& =-\left.\frac{2 \pi}{p} \cdot\left(r \cdot E_{\varphi}(p, r, z=h)\right)\right|_{0} ^{R_{1}}
\end{aligned}
$$

Taking into account formulas (7), (9) after the transition to the space of the originals we find the amplitude dependence $\Phi_{\mathrm{hm}}$ for the magnetic flux in the solenoid window of the inductor system. Omitting intermediate identical transformations, we obtain that

$$
\Phi_{\mathrm{hm}}=J_{\mathrm{m}} \cdot \frac{\mu_{0} \pi R_{1}}{\left(R_{2}-R_{1}\right)} \cdot \int_{0}^{\infty} f(\lambda) \cdot \operatorname{th}(\lambda h) \cdot J_{1}\left(\lambda R_{1}\right) d \lambda .
$$

The inductance of this system is found as the ratio of magnetic flux to excitation current [14].

After entering a new integration variable $y=\lambda R_{1}$ and perform the necessary identical transformations we obtain a convenient formula for calculating the inductance at any distance from the solenoid to the sheet metals

$$
L_{\mathrm{h}}=\frac{\mu_{0} \pi R_{1}^{2}}{\left(R_{2}-R_{1}\right)} \cdot \int_{0}^{\infty} \frac{f\left(y, R_{1,2}\right)}{y^{2}} \cdot \operatorname{th}(\lambda h) \cdot J_{1}(y) d y,
$$

where $f\left(y, R_{1,2}\right)=\int_{y}^{\left(y \cdot \frac{R_{2}}{R_{1}}\right)} x \cdot J_{1}(x) d x$.

The limit transition in (11) for $h \rightarrow \infty$ gives an expression for the inductance of the actual solenoid winding in the absence of sheet metals

$$
L_{\propto}=\lim _{h \rightarrow \infty} L_{\mathrm{h}}=\frac{\mu_{0} \pi R_{1}^{2}}{\left(R_{2}-R_{1}\right)} \cdot \int_{0}^{\infty} \frac{f\left(y, R_{1,2}\right)}{y^{2}} \cdot J_{1}(y) d y .
$$

Ultimately, the use of relations (1), (11), (12) allows us to proceed to numerical estimations of the impact of induction effects on the characteristics of electromagnetic processes in the studied inductor system. The results of the calculations are presented in Fig. 2.
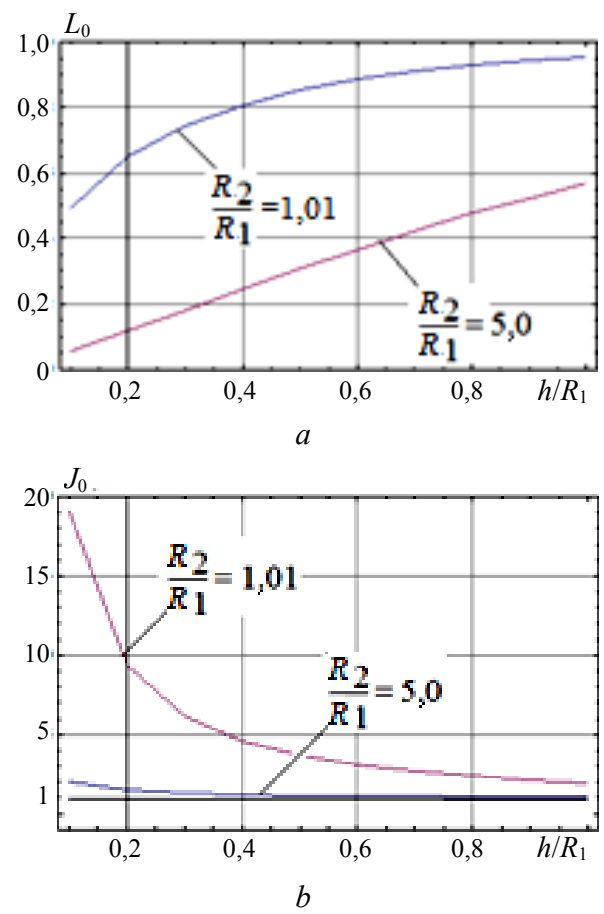

Fig. 2. Relative inductance $(a)$ and relative current $(b)$ in the solenoid winding of the inductor system

The main results of the calculations are formulated in the following provisions:

- the influence of induction effects on electromagnetic processes in the high-frequency mode of the studied 
inductor system showed that its inductance increases with the removal of massive conductors and decreases as they approach the solenoid, as well as with increasing its radial size (Fig. 2,a);

- the mentioned decrease in inductance requires an increase in the current in the solenoid winding to maintain a constant value of the excited magnetic flux density and constant force indicators (Fig. 2,b);

- as follows from the calculated data, to maintain the characteristics of the studied inductor system, on average, a possible increase in the excitation current by $\sim 20$ times is required (Fig. 2,b).

Conclusions and prospects for further development. For the first time for flat magnetic pulse stamping the design of the tool with the circular solenoid placed between the massive well-conducting metal objects which are subject to processing is proposed.

In the approximation of high-frequency electromagnetic processes, the calculation relationships are obtained, which are used to perform theoretical analysis and numerical estimations of the characteristics of a flat inductor system with variation of the working gap between the solenoid - a source of the field and the objects being processed.

It is shown that the inductance, as the main characteristic of the studied system, decreases when the processed objects approach the solenoid and increases at a distance from it, which is physically explained by the interaction of electromagnetic fields of exciting and induced currents.

It is obtained that in order to keep the force indicators of the proposed tool of magnetic pulse stamping, it is necessary to accordingly and obligatory adjust the amplitude of the excitation current in the winding of the solenoid - a source of the acting electromagnetic fields.

In conclusion, the authors would like to note the reasoning that expands the scope of practical application of the results of the work performed. As it seems a priori, a similar design of a flat air current transformer (matching device in MPTM), where a multi-turn circular solenoid connected to a power source should be placed between single-turn solenoids with electrically parallel load output, which can significantly reduce energy dissipation into the surrounding space. Such a device can become an element of energy-saving technologies in modern converter engineering.

Conflict of interest. The authors of the paper declare no conflict of interest.

\section{REFERENCES}

1. Benenson W., Harris J.W., Stöcker H., Lutz H. Handbook of Physics. Springer Nature Switzerland AG, 2002. 1190 p. doi: https://doi.org/10.1007/0-387-21632-4.

2. Gnatov A., Argun S. New Method of Car Body Panel External Straightening: Tools of Method. International Journal of Vehicular Technology, 2015, vol. 2015, pp. 1-7. doi: https://doi.org/10.1155/2015/192958.

3. Kudasov Y.B., Surdin O.M., Platonov V.V., Kozabaranov R.V., Maslov D.A., Makarov I.V., Svetlov A.S., Popov E.Y.
Metal plate deformation under magnetic field pulse of complex shape. Journal of Applied Physics, 2019, vol. 126, no. 8, p. 084901. doi: https://doi.org/10.1063/1.5108823.

4. Du L., Li X., Xia L., Zhang X., Lai Z., Han X., Li L., Cao Q. Numerical and experimental verification of an iterative coupling method for analyzing the Lorentz-force-driven sheet metal stamping process. The International Journal of Advanced Manufacturing Technology, 2021, vol. 115, no. 7-8, pp. 21612173. doi: https://doi.org/10.1007/s00170-021-07268-z.

5. Bay F., Jeanson A.-C., Zapata J.A. Electromagnetic Forming Processes: Material Behaviour and Computational Modelling. Procedia Engineering, 2014, vol. 81, pp. 793-800. doi: https://doi.org/10.1016/j.proeng.2014.10.078.

6. Ouyang S., Li C., Du L., Li X., Lai Z., Peng T., Han X., Cao Q., Li L. Electromagnetic forming of aluminum alloy sheet metal utilizing a low-frequency discharge: A new method for attractive forming. Journal of Materials Processing Technology, 2021, vol. 291, p. 117001. doi: https://doi.org/10.1016/j.jmatprotec.2020.117001.

7. Ouyang S., Du L., Cao Q., Li L. Electromagnetic attractive forming of aluminum alloy sheets utilizing a low-frequency half-wave current. Materials and Manufacturing Processes, 2021, pp. 1-9. doi: https://doi.org/10.1080/10426914.2021.1944197.

8. Batygin Y.V., Chaplygin E.A. Vortical currents in flat metallic sheet. Electrical Engineering \& Electromechanics, 2006, no. 5, pp. 54-59. (Rus). Available at: http://eie.khpi.edu.ua/issue/view/6513/2466 (accessed 25 June 2021).

9. Turenko A.N., Batygin Yu.V., Gnatov A.V. Impul'snye magnitnye polia dlia progressivnykh tekhnologii. T. 3. Teoriia $i$ eksperiment pritiazheniia tonkostennykh metallov impul'snymi magnitnymi poliami [Pulsed magnetic fields for advanced technologies. Vol. 3. Theory and experiment of the attraction of thin-walled metals by pulsed magnetic fields]. Kharkiv, KhNAHU Publ., 2009. 240 p. (Rus).

10. Batygin Yu., Barbashova M., Sabokar O. Electromagnetic Metal Forming for Advanced Processing Technologies. Cham, Springer International Publ. AG., 2018. 93 p. doi: https://doi.org/10.1007/978-3-319-74570-1.

11. Golovashchenko S.F., Batygin Yu.V. Sheet metal blank destacker. Patent US. US2018105373-A1, 04/19/2018.

12. Batygin Yu.V., Chaplygin E.A., Shinderuk S.A., Strelnikova V.A. The main inventions for technologies of the magneticpulsed attraction of the sheet metals. A brief review. Electrical Engineering \& Electromechanics, 2018, no. 3, pp. 43-52. doi: https://doi.org/10.20998/2074-272X.2018.3.06.

13. Kudasov Y.B., Makarov I.V., Platonov V.V., Surdin O.M., Maslov D.A., Voronov S.L., Malyshev A.Y., Korshunov A.S., Popov E.Y., Svetlov A.S. An Experimental Setup for Studying the Deformation Dynamics of Metal Samples under Pulsed Magnetic Field. Instruments and Experimental Techniques, 2019, vol. 62, no. 1, pp. 88-92. doi: https://doi.org/10.1134/s0020441219010135.

14. Demirchyan K.S., Neiman L.R., Korovkin N.V., Chechurin V.L. Teoreticheskie osnovy elektrotekhniki. 4 izd. T. 3 [Theoretical Foundations of Electrical Engineering, 4th ed., Vol. 3]. St. Petersburg, Peter Publ., 2006. 318 p. (Rus).

15. Isaev Yu., Vasilieva O. Metody rascheta elektromagnitnykh polei [Methods for calculating electromagnetic fields]. LAP Lambert Academic Publ., 2012. 172 p. (Rus).

16. Altenbach H., Konkin V., Lavinsky D., Morachkovsky O., Naumenko K. Verformungsanalyse elektrisch leitender metallischer Bauteile bei Magnetimpulsbearbeitung. Forschung 
im Ingenieurwesen, 2018, vol. 82, no. 4, pp. 371-377. (Ger). doi:

https://doi.org/10.1007/s10010-018-0285-x.

17. Lavinskii D.V., Morachkovskii O. K. Elastoplastic

Deformation of Bodies Interacting Through Contact Under the Action of Pulsed Electromagnetic Field. Strength of Materials, 2016, vol. 48, no. 6, pp. 760-767. doi: https://doi.org/10.1007/s11223-017-9822-3.

18. Kantorovich L. Mathematics for Natural Scientists. Fundamentals and Basics. Springer Nature Switzerland AG, 2016. 526 p. doi: https://doi.org/10.1007/978-1-4939-2785-2.

19. Weber H., Ulrich H. Laplace-, Fourier- und zTransformation. Springer Nature Switzerland AG, 2012. 236 p. doi: https://doi.org/10.1007/978-3-8348-8291-2.

Yu.V. Batygin ${ }^{1}$, Doctor of Technical Science, Professor, S.O. Shinderuk ${ }^{1}, P h D$, Associate Professor, E.O. Chaplygin ${ }^{1}, P h D$, Associate Professor.

${ }^{1}$ Kharkiv National Automobile and Highway University, 25, Yaroslava Mudrogo Str., Kharkiv, 61002, Ukraine. e-mail: yu.v.batygin@gmail.com,

s.shinderuk.2016102@ukr.net (Corresponding author), chaplygin.e.a@gmail.com

How to cite this article:

Batygin Yu.V., Shinderuk S.O., Chaplygin E.O. Mutual influence of currents in a flat inductor system with solenoid between two massive conductors. Electrical Engineering \& Electromechanics, 2021, no. 6, pp. 25-30. doi: https://doi.org/10.20998/2074$\underline{272 X .2021 .6 .04}$. 